University of Nebraska - Lincoln

DigitalCommons@University of Nebraska - Lincoln

\title{
Latitudinal patterns of magnitude and interannual variability in net ecosystem exchange regulated by biological and environmental variables
}

Wenping Yuan

University of Oklahoma, wenpingyuancn@yahoo.com

Yiqi Luo

University of Oklahoma

Andrew D. Richardson

University of New Hampshire, arichardson@oeb.harvard.edu

Ram Oren

Duke University

Sebastiaan Luyssaert

University of Antwerpen, Belgium

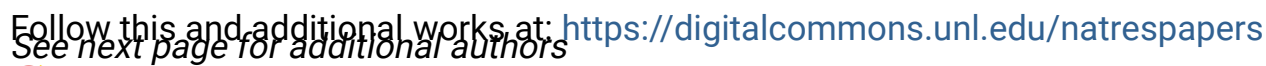

Part of the Natural Resources and Conservation Commons

Yuan, Wenping; Luo, Yiqi; Richardson, Andrew D.; Oren, Ram; Luyssaert, Sebastiaan; Janssens, Ivan A.; Ceulemans, Reinhart; Zhou, Xuhui; Grünwald, Thomas; Aubinet, Marc; Berhofer, Christian; Baldocci, Dennis D.; Chen, Jiquan; Dunn, Allison L.; DeForest, Jared L.; Dragoni, Danilo; Goldstein, Allen H.; Moors, Eddy; Munger, J. William William; Monson, Russell K.; Suyker, Andrew E.; Starr, Gregory; Scott, Russell L.; Tenhunen, John; Verma, Shashi; Vesala, Timo; and Wofsy, Steven C., "Latitudinal patterns of magnitude and interannual variability in net ecosystem exchange regulated by biological and environmental variables" (2009). Papers in Natural Resources. 180.

https://digitalcommons.unl.edu/natrespapers/180

This Article is brought to you for free and open access by the Natural Resources, School of at DigitalCommons@University of Nebraska - Lincoln. It has been accepted for inclusion in Papers in Natural Resources by an authorized administrator of DigitalCommons@University of Nebraska - Lincoln. 


\section{Authors}

Wenping Yuan, Yiqi Luo, Andrew D. Richardson, Ram Oren, Sebastiaan Luyssaert, Ivan A. Janssens, Reinhart Ceulemans, Xuhui Zhou, Thomas Grünwald, Marc Aubinet, Christian Berhofer, Dennis D. Baldocci, Jiquan Chen, Allison L. Dunn, Jared L. DeForest, Danilo Dragoni, Allen H. Goldstein, Eddy Moors, J. William William Munger, Russell K. Monson, Andrew E. Suyker, Gregory Starr, Russell L. Scott, John Tenhunen, Shashi Verma, Timo Vesala, and Steven C. Wofsy 


\title{
Latitudinal patterns of magnitude and interannual variability in net ecosystem exchange regulated by biological and environmental variables
}

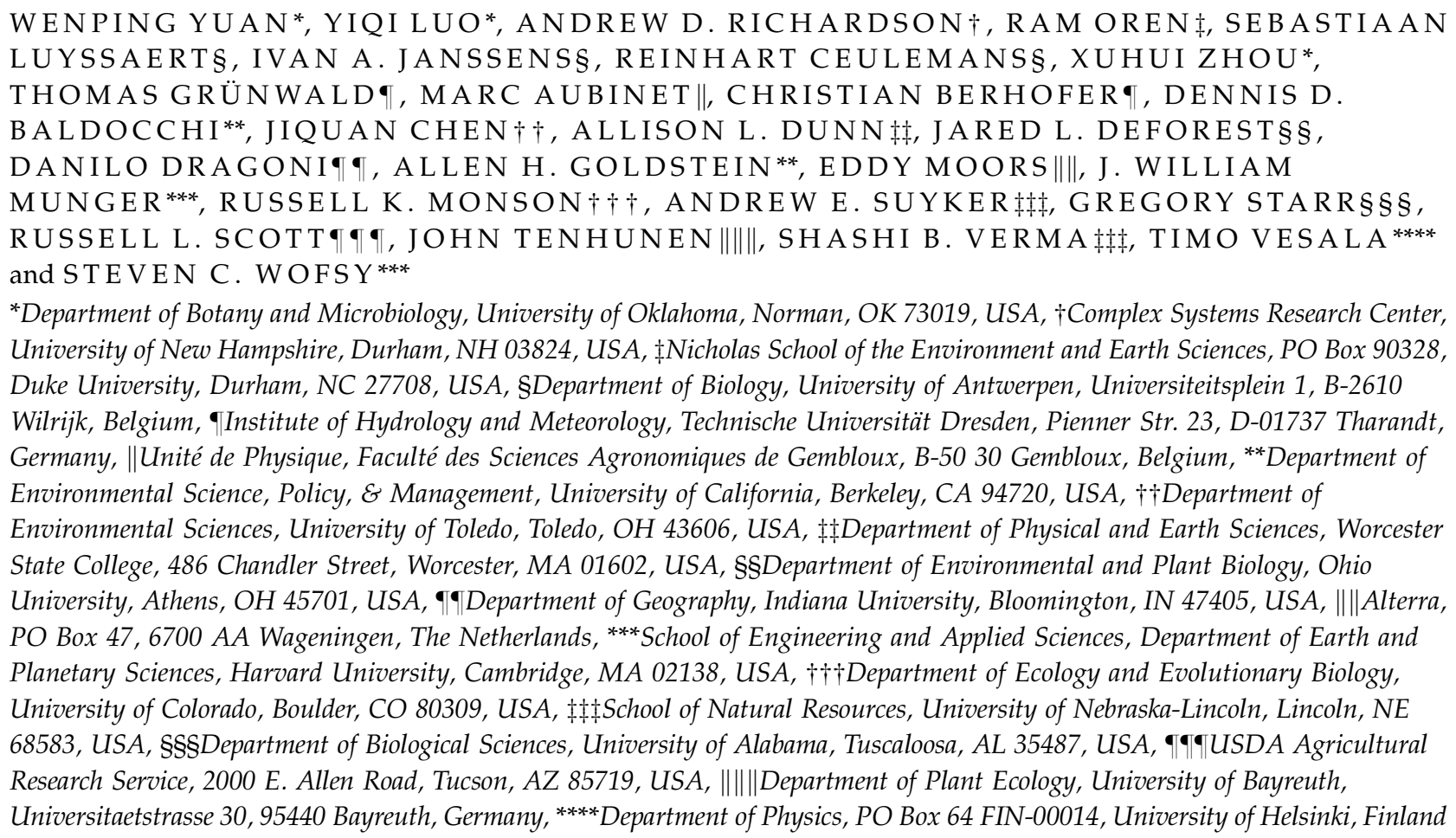

\begin{abstract}
Over the last two and half decades, strong evidence showed that the terrestrial ecosystems are acting as a net sink for atmospheric carbon. However the spatial and temporal patterns of variation in the sink are not well known. In this study, we examined latitudinal patterns of interannual variability (IAV) in net ecosystem exchange (NEE) of $\mathrm{CO}_{2}$ based on 163 site-years of eddy covariance data, from 39 northern-hemisphere research sites located at latitudes ranging from $\sim 29^{\circ} \mathrm{N}$ to $\sim 64^{\circ} \mathrm{N}$. We computed the standard deviation of annual NEE integrals at individual sites to represent absolute interannual variability (AIAV), and the corresponding coefficient of variation as a measure of relative interannual variability (RIAV). Our results showed decreased trends of annual NEE with increasing latitude for both deciduous broadleaf forests and evergreen needleleaf forests. Gross primary production (GPP) explained a significant proportion of the spatial variation of NEE across evergreen needleleaf forests, whereas, across deciduous broadleaf forests, it is ecosystem respiration (Re). In addition, AIAV in GPP and Re increased significantly with latitude in deciduous broadleaf forests, but AIAV in GPP decreased significantly with latitude in evergreen needleleaf forests. Furthermore, RIAV in NEE, GPP, and Re appeared to increase significantly with latitude in deciduous broadleaf forests, but not in evergreen needleleaf forests. Correlation analyses showed air temperature was the primary environmental factor that determined RIAV of NEE in
\end{abstract}

Correspondence: Wenping Yuan, tel. +1 605594 6526, e-mail:

wenpingyuancn@yahoo.com 
deciduous broadleaf forest across the North American sites, and none of the chosen climatic factors could explain RIAV of NEE in evergreen needleleaf forests. Mean annual NEE significantly increased with latitude in grasslands. Precipitation was dominant environmental factor for the spatial variation of magnitude and IAV in GPP and Re in grasslands.

Keywords: ecosystem respiration, eddy covariance, gross primary production, interannual variability, latitudinal pattern, net ecosystem exchange

Received 5 November 2008 and accepted 19 December 2008

\section{Introduction}

There is strong evidence that terrestrial ecosystems have acted as net carbon sinks over the last two and half decades, accounting for $20-30 \%$ of annual total anthropogenic $\mathrm{CO}_{2}$ emission into the atmosphere (Canadell et al., 2007). However, the geographic locations of this accumulation are not well known (Friend et al., 2007). Recent studies, using different approaches including biomass inventory, ecological models and inversions with atmospheric transport models, are inconclusive regarding the spatial distribution of carbon sinks (Fan et al., 1998; Gurney et al., 2002; Yuen et al., 2005). For example, Gurney et al. (2002) suggested the temperate North American carbon sink was approximately $40 \%$ smaller compared with what was reported by Fan et al. (1998), and a small boreal North American carbon source, rather than a small sink, was also reported. Furthermore, interannual variability (IAV) in integrated net ecosystem exchange (NEE) is a common phenomenon observed for almost all ecosystems worldwide (Goulden et al., 1996; Baldocchi et al., 2001) and the underlying variation in ecosystem metabolism causes significant year-to-year variability in the annual growth rate of atmospheric $\mathrm{CO}_{2}$ (Bousquet et al., 2000; Houghton, 2000). To date, however, the spatial patterns of IAV in NEE have not been characterized.

The objective of the present study is to characterize spatial patterns, in relation to latitude, of across-site variation in mean annual NEE, and within-site interannual variation in NEE. Latitude is a proxy for multiple environ-climatic variables and also vegetation attributes over large spatial scales. Indeed, it has been suggested that the thermal and water variables fluctuate differently from the equator to the poles (IPCC, 2001). For example, warming has generally increased with latitude at northern hemisphere, and average arctic temperatures increases at almost twice the global average rate in the past 100 years (IPCC, 2007). As to the precipitation, it increases over land north of $30^{\circ} \mathrm{N}$ over the period 1900 to 2005 but downward trends dominant the tropics since the 1970s (IPCC, 2007). Moreover, the standard deviation (SD) of temperature, indicating IAV in temperature, is greatest in high-latitude regions, and decreases toward the equator (Räisänen, 2002). Numbers of studies showed that temporal and spatial variations in climate along the latitudinal gradient strongly regulate spatial patterns in NEE (Jarvis et al., 2001; Oberbauer et al., 2007).

Most of synthesis analyses, however, assembled all ecosystem types, which masked the differences of responsive mechanisms to climate change among ecosystem types, suggesting the ambiguous spatial patterns of ecosystem carbon fluxes across the regional scales (Simmons et al., 1996; Oberbauer et al., 2007). Recent studies showed different biological and environmental regulations to ecosystem carbon fluxes among ecosystem types, which directly related to the latitudinal patterns of magnitude and IAV in NEE, gross primary production (GPP) and ecosystem respiration (Re). Some preliminary experimental evidences follow from recent studies demonstrating that the responses of deciduous broadleaf forests to temperature variation are much more sensitive than evergreen needleleaf forests (Arain et al., 2002; Welp et al., 2007). For example, increases in spring air temperatures from 2002 to 2004 resulted in increases of GPP during the spring by $74 \%$ and Re by $61 \%$ in a deciduous broadleaf forest, but in an adjacent evergreen needleleaf forest, however, the temperature only led to increases of GPP by $16 \%$ and Re by $15 \%$ (Welp et al., 2007). Consequently, spatial patterns of IAV in ecosystem carbon fluxes of deciduous broadleaf forest will abide by the variation of temperature, but there are complicated environmental controls on spatial patterns in evergreen needleleaf forests (Kljun et al., 2006; Stoy et al., 2008). Compared with the forest ecosystems, precipitation is dominant variable not only in the magnitude but also IAV of GPP, Re and NEE in grasslands based on studies at individual sites (Li et al., 2005; Jacobs et al., 2007).

Furthermore, it has been well established that the magnitudes of NEE vary with latitude in forest ecosystems (Valentini et al., 2000; Jarvis et al., 2001; van Dijk \& Dolman, 2004). In general, NEE rates are large in the low latitudinal regions and become smaller in the high latitudinal regions. However, it has been debated which 
of GPP and Re is dominant in determining geographical distributions of NEE (Janssens et al., 2001; Barr et al., 2002). A recent study suggested annual Re accounted for a larger degree of the variability in annual NEE $\left(R^{2}=0.6\right)$ at deciduous broadleaf forest than did GPP $\left(R^{2}=0.1\right)$, in contrast, GPP was significantly related to NEE at the adjacent evergreen needleleaf forest (Stoy et al., 2008). Therefore, it is crucial to study the similarities and differences, in terms of degree, mechanism, and process, of biological and environmental regulation to ecosystem carbon fluxes across various ecosystem types, in order to reliably characterize the spatial patterns of magnitude and IAV in NEE.

Continuous, high frequency, tower-based eddy covariance $(\mathrm{EC})$ measurements of the surface-atmosphere exchange of $\mathrm{CO}_{2}$, now being made at hundreds of sites around the world, permit quantification of site-level carbon balances. Concurrent measurements of environ-climatic drivers, such as temperature, photosynthetically active radiation (PAR) and precipitation, provide the data necessary to investigate how variation in these factors drives variation in NEE, GPP and Re. Furthermore, as $\mathrm{CO}_{2}$ flux measurements are now being made in a wide range of biomes, it is of clear value to investigate the differences of responsive mechanisms to climate change among biomes. Therefore, the overarching goal of this study is to investigate latitudinal patterns of NEE and its IAV, and identify underlying mechanisms based on EC flux measurements. Specific objectives are to (1) analyze latitudinal patterns of NEE, GPP, and Re in terms of their mean values and IAVs, (2) investigate the contributions of GPP and Re to spatial variation of NEE, and (3) examine environ-climatic regulation of these patterns.

\section{Data and methods}

\section{EC flux data}

The data used in this study were downloaded from the Ameriflux (http://public.ornl.gov/ameriflux) and EuroFlux internet webpages (http://www.fluxnet.ornl.gov/fluxnet/index.cfm; Valentini, 2003). Supplementary information on the vegetation, climate, and soils at each site is available on-line. Half-hourly or hourly averaged PAR, air temperature $\left(T_{\mathrm{a}}\right)$, precipitation (Prec), and friction velocity $\left(u^{*}\right)$ were used together with EC fluxes of $\mathrm{CO}_{2}\left(F_{\mathrm{c}}\right)$, and latent heat (LE) in this study. When available, datasets that were gap-filled by site PIs were used for this study. For other sites, data filtering and gap-filling was conducted according to the following procedures.

An outlier (spike) detection technique was applied, and the spikes were removed, following Papale et al.
(2006). Because nighttime $\mathrm{CO}_{2}$ flux can be underestimated by EC measurements under stable conditions (Falge et al., 2001), nighttime data with nonturbulent conditions were removed based on a $u^{*}$-threshold criterion (site-specific 99\% threshold criterion following Reichstein et al., 2005, and Papale et al., 2006).

Nonlinear regression methods were used for filling $F_{\mathrm{c}}$ data gaps (Falge et al., 2001) and partitioning NEE to GPP and Re (Desai et al. 2008). The nonlinear regression procedure (PROC NLIN) in the STATISTICAL ANALYSIS SYSTEM (SAS Institute Inc., Cary, NC, USA) was applied to fit the relationships between measured fluxes and controlling environ-climatic using a 15-day moving window. The Van't Hoff ( $Q_{10}$; see Lloyd \& Taylor, 1994) equation was used to fill the missing nighttime fluxes $\left(F_{\mathrm{c}, \text { night }}\right)$ :

$$
F_{\mathrm{c}, \text { night }}=A \mathrm{e}^{\left(B T_{a}\right)} \text {, }
$$

where, $A$ and $B$ are fit model parameters. A MichaelisMenten light response equation was used to fill the missing daytime fluxes $\left(F_{\mathrm{c}, \text { day }}\right)$ (Falge et al., 2001):

$$
F_{\mathrm{c}, \text { day }}=\frac{\alpha \times P A R \times F_{\mathrm{GPP}, \mathrm{sat}}}{F_{\mathrm{GPP}, \text { sat }}+\alpha \times P A R}-F_{\mathrm{RE}, \text { day }},
$$

where $F_{\mathrm{GPP}, \text { sat }}$ (gross primary productivity at saturating light) and $\alpha$ (initial slope of the light response function) are fit parameters, and $F_{\mathrm{RE} \text {,day }}$ (ecosystem respiration during the day) was estimated by extrapolation of Eqn (1) using the daytime air temperature.

Daily NEE, Re, and meteorological variables were synthesized based on half-hourly or hourly values and the daily values were indicated as missing when missing data was $>20 \%$ of entire data at a given day, otherwise daily values were calculated by multiplying averaged hourly rate by 24 (hours). GPP was calculated as the sum of NEE and Re. Based on the daily data set, yearly variables values can be calculated by multiplying averaged daily rate by 365 (days). If missing daily data was $>20 \%$ of entire year data, the value of this year was indicated as missing. On average, $30 \%$ of the year was rejected due to insufficient daily observation. The years rejected varied among sites from $60 \%$ (Blodgett) to $10 \%$ (Harvard forest).

For a site to be included in this study it had to meet the following criteria: minimum of 2 years of NEE and $\mathrm{Re}$, as well as all meteorological variables. Based on this criterion, 39 sites consisting of 163 years were included for analyzing latitudinal patterns, covering three major terrestrial biomes: deciduous broadleaf forests, evergreen needleleaf forests, and grasslands (Table 1).

\section{Other calculations}

Water balance index (WBI) was calculated from the difference between daily evapotranspiration (ET), de- 
Table 1 Sites characteristic in this study

\begin{tabular}{|c|c|c|c|c|c|c|}
\hline Site & Type & Latitude $\dagger$ & Longitude $\ddagger$ & Stand age (years) & Available years & Reference \\
\hline Bartlett forest & DBF & 44.06 & -71.29 & 95 & 2004-2005 & Richardson et al. (2007b) \\
\hline Duke Hardwood & DBF & 35.98 & -79.11 & $80-100$ & 2001-2005 & Pataki \& Oren (2003) \\
\hline Harvard forest & DBF & 42.54 & -72.17 & $100-230$ & 1993-2004 & Urbanski et al. (2007) \\
\hline Indiana MMSF & $\mathrm{DBF}$ & 39.33 & -86.41 & $60-90$ & 2001-2005 & Schmid et al. (2000) \\
\hline Sarrebourg & DBF & 48.67 & 7.08 & 30 & 1997-1999 & Granier et al. (2000) \\
\hline Soroe & $\mathrm{DBF}$ & 55.48 & 11.65 & 78 & 1997-1999 & Pilegaard et al. (2001) \\
\hline Walker Brach & $\mathrm{DBF}$ & 35.96 & -84.29 & $50-120$ & 1999-2001; 2006 & Wilson \& Baldocchi (2000) \\
\hline Willow Creek & $\mathrm{DBF}$ & 45.91 & -90.08 & $60-80$ & 2002-2003 & Bolstad et al. (2004) \\
\hline Aberfeldy & ENF & 56.60 & 3.80 & 14 & 1997-1998 & Valentini et al. (2000) \\
\hline Bayreuth & ENF & 50.20 & 11.87 & 40 & 1997-1999 & Valentini et al. (2000) \\
\hline Blackhill & ENF & 44.20 & -103.70 & - & 2005-2006 & - \\
\hline Blodgett & ENF & 38.90 & -120.60 & 10 & 2000-2003 & Goldstein et al. (2000) \\
\hline Brasschaat & ENF & 51.30 & 4.52 & 67 & 1997-1999 & Carrara et al. (2003) \\
\hline Duke Pine & ENF & 36.00 & -79.10 & 17 & 1998-2005 & Stoy et al. (2006) \\
\hline Flakaliden & ENF & 64.10 & 19.45 & 31 & 1997-1998 & Lindroth et al. (1998) \\
\hline Howland & ENF & 45.20 & -68.74 & $95-140$ & 1996-2004 & Hollinger et al. (2004) \\
\hline Howland West & ENF & 45.20 & -68.75 & $95-140$ & 1999-2001 & Hollinger et al. (2004) \\
\hline Hyytiälä & ENF & 61.90 & 24.28 & 30 & 1997-2000 & Suni et al. (2003) \\
\hline Loobos & ENF & 52.20 & 5.74 & 80 & 1997-2000 & Dolman et al. (2002) \\
\hline Metolius Midpine & ENF & 44.50 & -121.60 & 56 & 2002-2005 & Law et al. (2004) \\
\hline Metolius New-young & ENF & 44.30 & -121.60 & 18 & 2004-2005 & - \\
\hline Metolius Old-young & ENF & 44.40 & -121.60 & 15 & 2000-2002 & Law et al. (2000) \\
\hline Niwotridge & ENF & 40.00 & -105.60 & 100 & 1999-2004 & Monson et al. (2005) \\
\hline Tharandt & ENF & 50.95 & 13.56 & 120 & 1997-2006 & Grünwald \& Berhofer (2007) \\
\hline Uci1964 & ENF & 55.90 & -98.38 & 43 & 2002-2004 & Goulden et al. (2006) \\
\hline Donaldson & ENF & 29.80 & -82.16 & $11-13$ & 2001-2003 & Gholz \& Clark (2002) \\
\hline Windriver & ENF & 45.82 & -121.95 & 500 & 2001-2004 & Paw et al. (2004) \\
\hline Boreas_nsa & ENF & 55.88 & -98.48 & $90-120$ & 1994-2006 & Dunn et al. (2007) \\
\hline Parkfalls & ENF & 45.94 & -90.27 & $60-80$ & 1997-2001 & - \\
\hline Uci1850 & ENF & 55.88 & -98.48 & 150 & 2003-2004 & - \\
\hline Audubon & GRS & 31.59 & -110.51 & - & 2004-2006 & - \\
\hline Brooking & GRS & 44.34 & -96.84 & - & 2005-2006 & - \\
\hline Duke grass & GRS & 35.98 & -79.10 & - & 2001-2005 & Novick et al. (2004) \\
\hline Lethbridge & GRS & 49.71 & -112.94 & - & 2002-2004 & Flanagan \& Johnson (2005) \\
\hline Shidler, OK & GRS & 36.93 & -96.68 & - & 1998-1999 & Suyker \& Verma (2001) \\
\hline Vairaranch & GRS & 38.41 & -120.95 & - & 2001-2003; 2006 & Baldocchi et al. (2004) \\
\hline Walnut River & GRS & 51.52 & -96.86 & - & 2000-2003 & Song et al. (2005) \\
\hline Santa Rita & GRS(SAV) & 31.82 & -110.90 & - & 2005-2006 & Scott et al. (2008) \\
\hline Tonzi Ranch & GRS(SAV) & 38.42 & -120.95 & - & 2002-2006 & Baldocchi et al. (2004) \\
\hline
\end{tabular}

$†$ Values indicate north latitude.

$\ddagger$ Positive values indicate east longitude, and negative values indicate west longitude.

DBF, deciduous broadleaf forests; ENF, evergreen needleleaf forests; GRS, grasslands; SAV, savanna ecosystem.

rived from EC measurements of LE, and daily precipitation (Prec), summed over the year as an indicator of water limitation (Law et al., 2002).

$$
\mathrm{WBI}=\mathrm{ET}-\text { Prec. }
$$

We used the SD of annual flux sums to characterize the absolute interannual variability (AIAV), and coefficient of variation $(\mathrm{CV}$; the ratio of $\mathrm{SD}$ and mean value of annual flux sums) to characterize the relative interannual variability (RIAV).

We used the sum of squared deviation to characterize the seasonal variation of climatic factors (Hui et al., 2003), calculated as:

$$
S S=\sum_{j=1}^{n}\left(\overline{x_{j}}-\bar{x}\right)^{2}
$$


where $\overline{x_{j}}$ is the mean of $j$ th day environmental variables across all years within one site, $\bar{x}$ is the mean of the environmental variables for all days, $n$ is number of all days.

Many sites only had 2 or 3 years of available data (Table 1), and the probability of the study year involving abnormal climatic conditions was magnified, which would possibly result in extremely high IAV of carbon balance resulting in extreme deviation of analyzed patterns of carbon balance from the normal situation. Therefore, it was indispensable to investigate the robustness of data before analyses. There were 33\% and $17 \%$ of the sites we examined which had 2 and 3 years of available data respectively, which accounted for the half of all sites. Our analysis indicated that the values of $\mathrm{SD}$ and $\mathrm{CV}$ in 2-year group were smaller compared with the most groups ( $t$-test, $P<0.05$; Fig. 1). Although, the large SD and CV of GPP and Re were found in 3-year group, but did not have significant differences with the 5 years or more than 5 years data groupings (Fig. 1). Furthermore, no significant correlations were found between $\mathrm{SD}$ or $\mathrm{CV}$ and the number of available years (data not shown), indicating estimated $\mathrm{SD}$ and $\mathrm{CV}$ were robust for analyzing in this study.

\section{Results}

\section{Latitudinal patterns of annual GPP, Re, and NEE}

The mean rate of NEE varied greatly with different ecosystems. NEE was highest in deciduous broadleaf forests $\left(249 \pm 75 \mathrm{~g} \mathrm{C} \mathrm{m}^{-2} \mathrm{yr}^{-1}\right)$, intermediate in evergreen needleleaf forests $\left(189 \pm 50 \mathrm{gC} \mathrm{m}^{-2} \mathrm{yr}^{-1}\right)$, and they were both significant larger $(t$-test, $P<0.05)$ than that in grasslands $\left(19 \pm 31 \mathrm{~g} \mathrm{C} \mathrm{m}^{-2} \mathrm{yr}^{-1}\right)$. On the contrary, there were no significant differences in AIAV and RIAV among three ecosystems ( $t$-test, $P<0.05)$. On average, AIAV was $72 \pm 7 \mathrm{~g} \mathrm{C} \mathrm{m}^{-2} \mathrm{yr}^{-1}$ across all sites, and RIAV was $0.97 \pm 0.27$.

Our analyses did not show consistent latitudinal patterns of GPP, Re, and NEE among three vegetation types: deciduous broadleaf forests, evergreen needleleaf forests, and grasslands. The annual GPP decreased significantly with increasing latitude $\left(-27 \pm 10 \mathrm{~g} \mathrm{C} \mathrm{m}^{-2}\right.$ $\mathrm{yr}^{-1}$ per degree; $\left.R^{2}=0.24, P<0.05\right)$ in evergreen needleleaf forests, (Fig. 2b). In grasslands and deciduous broadleaf forests, we were unable to detect a significant relationship between GPP and latitude (Fig. 2a and c). The annual Re decreased significantly with increasing (a)

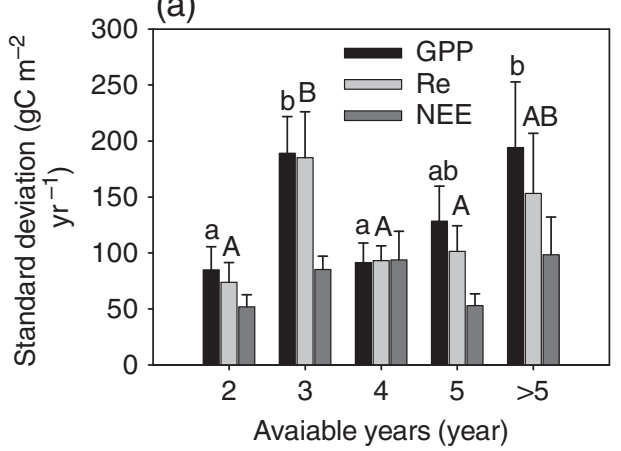

(b)

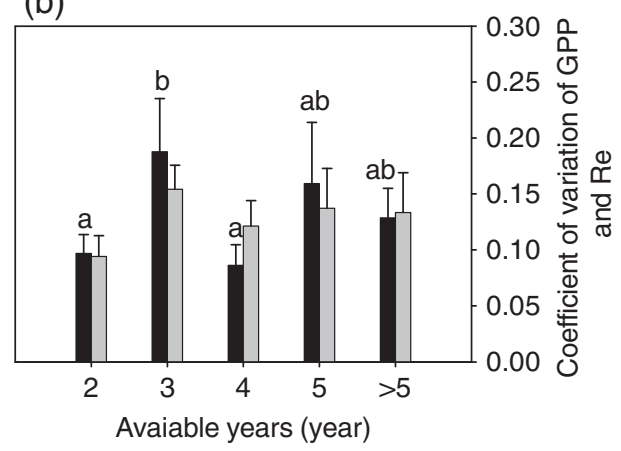

(c)

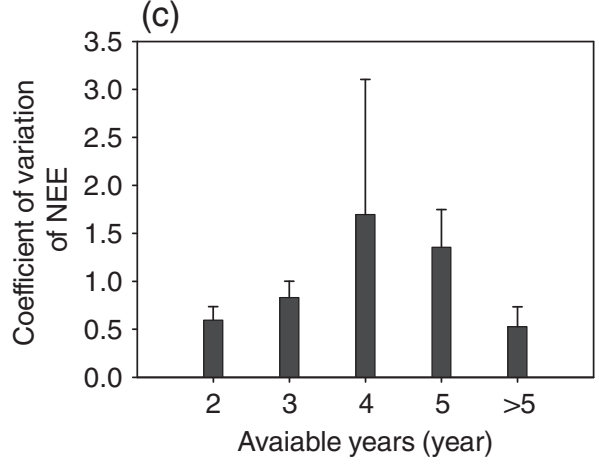

Fig. 1 The robustness of estimated standard deviation (SD) of GPP, Re and NEE (a), coefficient of variation (CV) of GPP and Re (b) and CV of NEE (c). Error bars show standard errors, and little letters indicate the differences on SD and CV of GPP $(P<0.05)$ among groups, and capital letters indicate the differences on SD of Re among groups. NEE, net ecosystem exchange; GPP, gross primary production; Re, ecosystem respiration. 

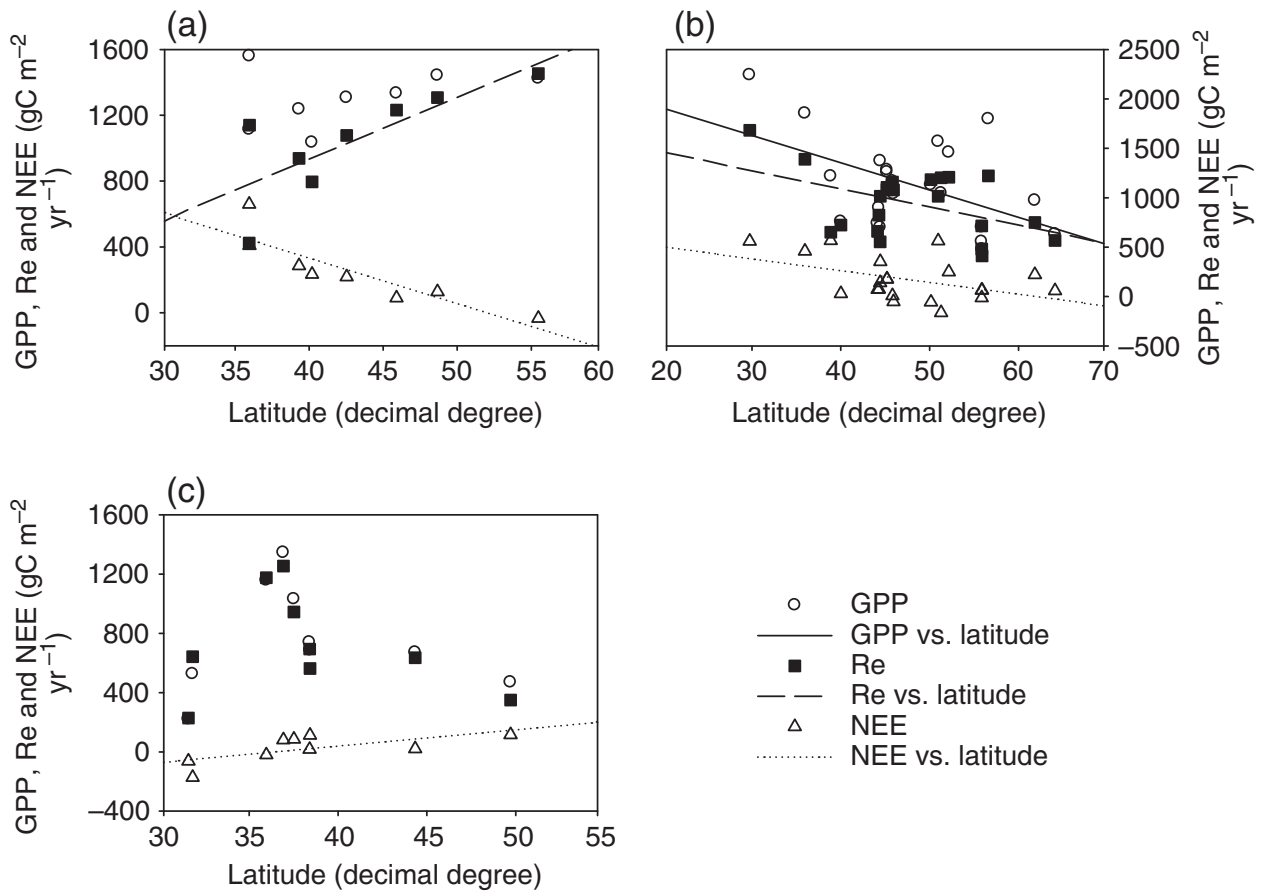

Fig. 2 Latitudinal patterns of GPP, Re and NEE in different ecosystems: (a) deciduous broadleaf forests; (b) evergreen needleleaf forests; (c) grasslands. Positive values at $y$-axes indicate that carbon is absorbed by the ecosystems, while negative values indicate that carbon is released by the ecosystems to the atmosphere. The regression lines are presented, in (a) $\operatorname{Re}=37 \mathrm{Lat}-570, R^{2}=0.60, P<0.01$; $\mathrm{NEE}=-28 \mathrm{Lat}+1438, R^{2}=0.76, P<0.01 ;$ in $(\mathrm{b}) \mathrm{GPP}=-27 \mathrm{Lat}+2449, R^{2}=0.24, P<0.05 ; \operatorname{Re}=-18$ Lat $+1835, R^{2}=0.22, P<0.05$; $\mathrm{NEE}=-11$ Lat $+730, R^{2}=0.20, P<0.05$; in (c) NEE $=10$ Lat $-399, R^{2}=0.44, P=0.05$. Lat, latitude; NEE, net ecosystem exchange; GPP, gross primary production; Re, ecosystem respiration.

latitude $\left(-18 \pm 8 \mathrm{~g} \mathrm{C} \mathrm{m}^{-2} \mathrm{yr}^{-1}\right.$ per degree; $R^{2}=0.22$, $P<0.05$ ) in evergreen needleleaf forests (Fig. 2b), increased significantly with increasing latitude $(37 \pm 13$ $\mathrm{gC} \mathrm{m}^{-2} \mathrm{yr}^{-1}$ per degree; $\left.R^{2}=0.60, P<0.01\right)$ in deciduous broadleaf forests (Fig. 2a), and was not significantly correlated with latitude in grasslands. Across different ecosystem types, there were distinctly different patterns of variation in annual NEE with regard to the latitude (Fig. 2a-c). For forested ecosystems, carbon sequestration rates were lower at high than low-latitude, and latitudinal trends were significant both in deciduous broadleaf forests $\left(-28 \pm 6 \mathrm{~g} \mathrm{C} \mathrm{m}^{-2} \mathrm{yr}^{-1}\right.$ per degree; $\left.R^{2}=0.76, P<0.01\right)$ and evergreen needleleaf $\left(-11 \pm 5 \mathrm{~g} \mathrm{C} \mathrm{m}^{-2} \mathrm{yr}^{-1}\right.$ per degree; $\left.R^{2}=0.2, P<0.05\right)$ forests. In contrast, high-latitude grasslands sequestered significantly more carbon than low-latitude grasslands $\left(10 \pm 4.6 \mathrm{~g} \mathrm{C} \mathrm{m}^{-2} \mathrm{yr}^{-1}\right.$ per degree; $R^{2}=0.44, P=0.05$; Fig. 2c).

Since NEE is a balance between GPP and Re, variations in NEE can be correlated with variations in GPP and $\operatorname{Re}$ among different sites (Fig. 3). In deciduous broadleaf forests, there was a significant negative correlation between NEE and $\operatorname{Re}$ (Fig. 3a; $R^{2}=0.74$, $P<0.01)$. However, variation in NEE appears more related to GPP than to Re in evergreen needleleaf forests (Fig. 3b; $R^{2}=0.49, P<0.01$ ). Neither GPP nor $\operatorname{Re}$ showed significant correlation with NEE in grasslands.

\section{Latitudinal patterns of IAV in GPP, Re, and NEE}

AIAV (measured by SD) in GPP and Re showed different latitudinal trends between deciduous broadleaf forests and evergreen needleleaf forests (Fig. 4a and b). The AIAV of GPP $\left(12 \pm 3.47 \mathrm{~g} \mathrm{C} \mathrm{m}^{-2} \mathrm{yr}^{-1}\right.$ per degree; $\left.R^{2}=0.69, P<0.01\right)$ and $\operatorname{Re}\left(16 \pm 2.52 \mathrm{gC} \mathrm{m}^{-2} \mathrm{yr}^{-1}\right.$ per degree; $\left.R^{2}=0.87, P<0.01\right)$ were positively correlated with latitude in deciduous broadleaf forests (Fig. 4a). However, AIAV of GPP $\left(-5.70 \pm 1.76 \mathrm{~g} \mathrm{C} \mathrm{m}^{-2} \mathrm{yr}^{-1}\right.$ per degree; $\left.R^{2}=0.34, P<0.05\right)$ and $\operatorname{Re}\left(R^{2}=0.04, P=0.36\right)$ were negatively correlated with latitude in evergreen needleleaf forests (Fig. 4b). For grasslands, AIAV in GPP $\left(R^{2}=0.08, P=0.44\right)$ and $\operatorname{Re}\left(R^{2}=0.03, P=0.62\right)$ were highly variable across sites, regardless of latitude, and for neither component flux was there a significant correlation with latitude (Fig. 4c).

Trends towards decreasing AIAV in NEE at higher latitudes were observed for both evergreen needleleaf forests and broadleaf deciduous forests, but for neither 

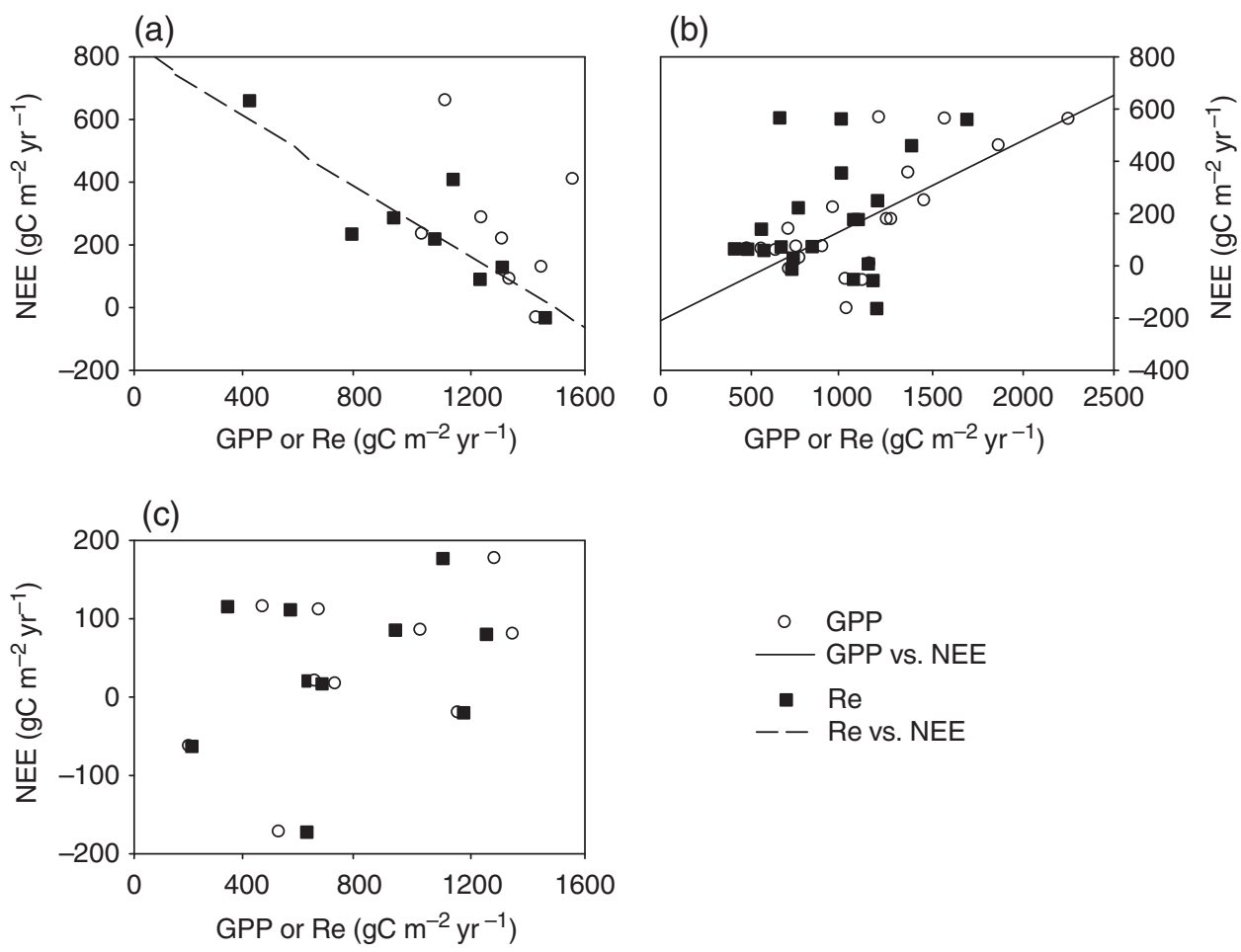

Fig. 3 Correlations of NEE with GPP and Re in (a) deciduous broadleaf forests, (b) evergreen needleleaf forests and (c) grasslands. The regression lines are presented if the correlations are significant, in (a) $\operatorname{Re}=-1.32 \mathrm{NEE}+1375, \quad R^{2}=0.74, \quad P<0.01 ; \quad(\mathrm{b})$ $\mathrm{GPP}=1.44 \mathrm{NEE}+850, R^{2}=0.49, P<0.01$. Positive values at $y$-axes indicate that carbon is absorbed by the ecosystems, while negative values indicate that carbon is released by the ecosystems to the atmosphere. NEE, net ecosystem exchange; GPP, gross primary production; Re, ecosystem respiration.

ecosystem types were these trends significant $\left(R^{2}=0.12, P=0.10\right.$ and $R^{2}=0.07, P=0.52$, respectively). For grasslands, AIAV in NEE was constant with latitude. RIAV (measured by CV) of GPP, Re, and NEE significantly increased with latitude only in deciduous broadleaf forests (Fig. 5a).

\section{Environmental correlation of IAV in GPP, Re, and NEE}

Mean rates of annual GPP, Re, and NEE did not show significant correlation with any environmental factors of $\mathrm{T}_{\mathrm{a}}$, Prec, PAR, LE, and WBI among three vegetation types, and seasonal variation of climatic factors also could not account for their variations, implying various ecosystems had distinct differences on dominant environmental factors. Mean rates of annual Re in deciduous broadleaf forests correlated negatively with the mean annual air temperature, while GPP tended to be constant with the temperature gradient. As a consequence, NEE was positively correlated with the mean annual air temperature (Table 2). In evergreen needleleaf forests, GPP, Re, and NEE increased significantly with air temperature (Table 2). GPP and Re also showed significantly positive correlation with annual precipitation in the evergreen needleleaf forests. Multiple regression equations of GPP and Re with temperature and precipitation were $\quad$ GPP $=68 \times T_{\mathrm{a}}+0.22 \times$ Prec $+504 \quad\left(R^{2}=0.72\right.$, $P<0.01), \quad \operatorname{Re}=39 \times T_{\mathrm{a}}+0.27 \times \operatorname{Prec}+443 \quad\left(R^{2}=0.69\right.$, $P<0.01)$, respectively. Annual precipitation was a major cause for spatial distributions of GPP and Re in grasslands (Table 2), however, no significant correlation was found with NEE.

In deciduous broadleaf forests, RIAV of air temperature had significant correlation with RIAV in GPP, Re, and NEE across the North American sites (Fig. 6; Table 2). IAV of annual precipitation was well correlated with IAV in GPP and Re in grasslands. AIAV of precipitation explained $40 \%$ and $63 \%$ variables of AIAV in GPP and Re, respectively, in grasslands, and RIAV of precipitation accounted for $41 \%$ and $56 \%$ variables of RIAV in GPP and Re (Table 2).

\section{Discussion}

\section{Spatial pattern in NEE along latitude}

Our analysis and many other studies have characterized the decreasing latitudinal patterns of NEE in forest 

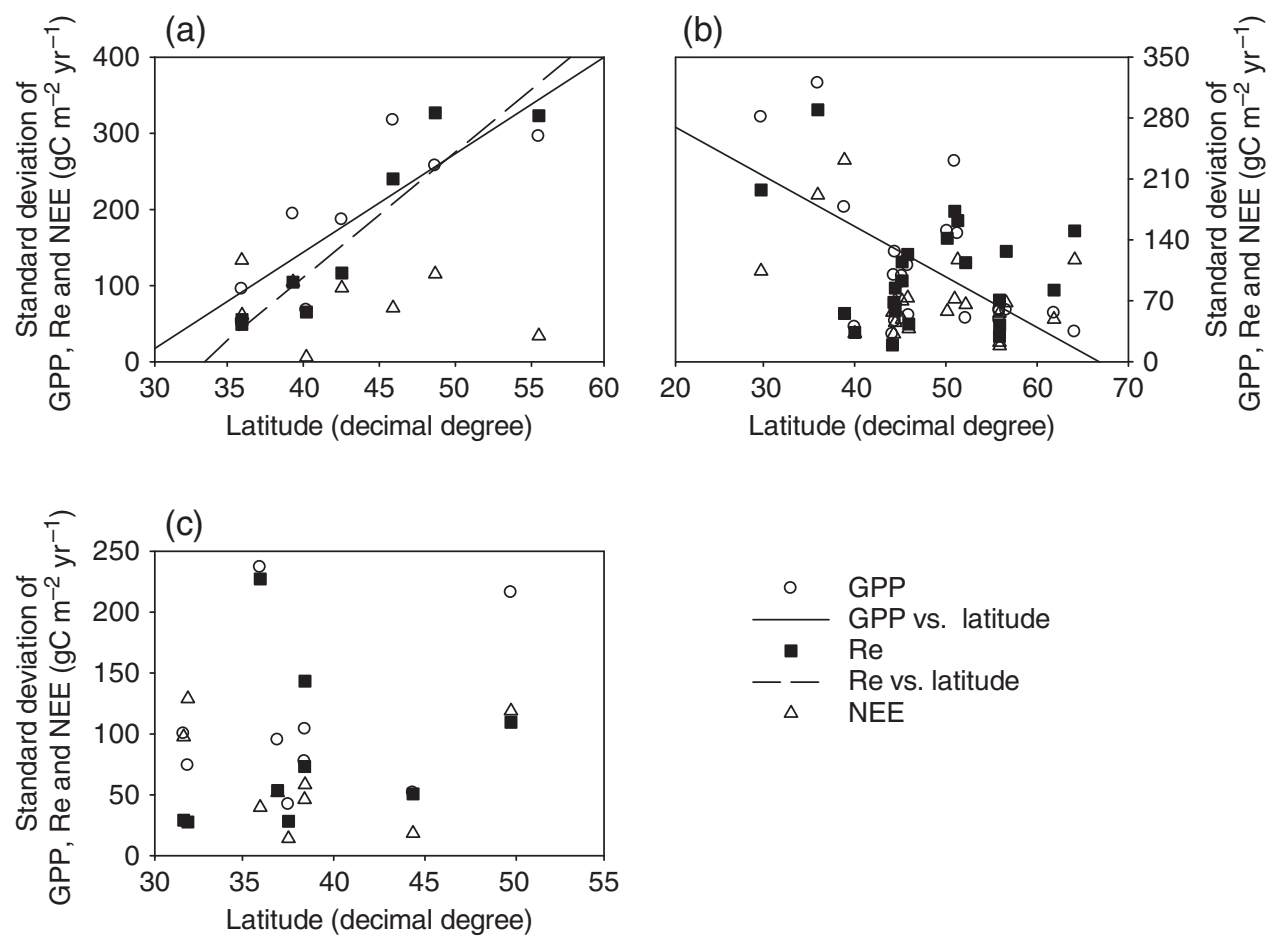

Fig. 4 Latitudinal patterns of standard deviation (SD) of GPP, Re, and NEE in different ecosystems: (a) deciduous broadleaf forests; (b) evergreen needleleaf forests; (c) grasslands. The regression lines are presented if the correlations are significant, in (a) GPP $=12 \mathrm{Lat}-364$, $R^{2}=0.69, P<0.01 ; \operatorname{Re}=16$ Lat $-548, R^{2}=0.87, P<0.01$; in (b) GPP $=-5.70$ Lat $+382, R^{2}=0.34, P<0.05$. Lat, latitude; NEE, net ecosystem exchange; GPP, gross primary production; Re, ecosystem respiration.

ecosystems (Valentini et al., 2000; Jarvis et al., 2001; van Dijk \& Dolman, 2004; Kato \& Tang, 2008), however it has been debated which of GPP and Re is dominant in determining geographical distributions of NEE (Janssens et al., 2001; Barr et al., 2002). Valentini et al. (2000) found that annual ecosystem respiration increases with latitude, while GPP tends to be constant across European forests, suggesting that respiration might be the determinant of the $\mathrm{CO}_{2}$ balance at the regional scale. van Dijk \& Dolman (2004), however, reported that the absolute value of GPP towards the pole decreases more rapidly than that of $R e$, which results in a decreasing latitude trend of NEE. Our results showed that the same latitudinal trends of NEE between these two forests stemmed from different responses of GPP and Re. In evergreen needleleaf forests, the decrease in GPP from mid- to high-latitudes was greater than the decrease in Re. A correlation analysis also showed GPP was responsible for the spatial variation of NEE (Fig. 3b). In contrast, for deciduous broadleaf forests, the increase in Re with increasing latitude accounted for the decline of NEE at higher latitudes (Fig. 3a).

Differences of physiological responses to environments might be the major cause for different determinant of NEE in these two ecosystems. In general, ecosystem experienced two different phenophases through the whole year, being carbon release and uptake because of the balance between GPP and Re. During the carbon sink period, GPP was dominant carbon flux in the ecosystem, and constrained Re as well as NEE (Janssens et al., 2001). However, vegetation retained dormancy or weak photosynthesis during the period of ecosystem carbon release, so Re governed the variations of NEE. Thus, the proportion of two phenophases period was important for the primary determinant of NEE through the whole year. In this study, the carbon uptake period, defined as the continuous period when 5-day running mean value of NEE was positive, in deciduous broadleaf forests was shorter than evergreen needleleaf forests in the same thermal regions because of slow recovery of plant canopy in spring and defoliation in autumn across the deciduous broadleaf forests (Fig. 7). For example, carbon uptake period in deciduous broadleaf forests was shorter by 86 days than evergreen needleleaf forests when mean annual temperature was $9{ }^{\circ} \mathrm{C}$ (Fig. 7). Other lines of evidences also showed that soil respiration was higher at the deciduous broadleaf than adjacent evergreen needleleaf forest, resulting from higher soil and forest floor moisture and temperature in the deciduous broadleaf forests 

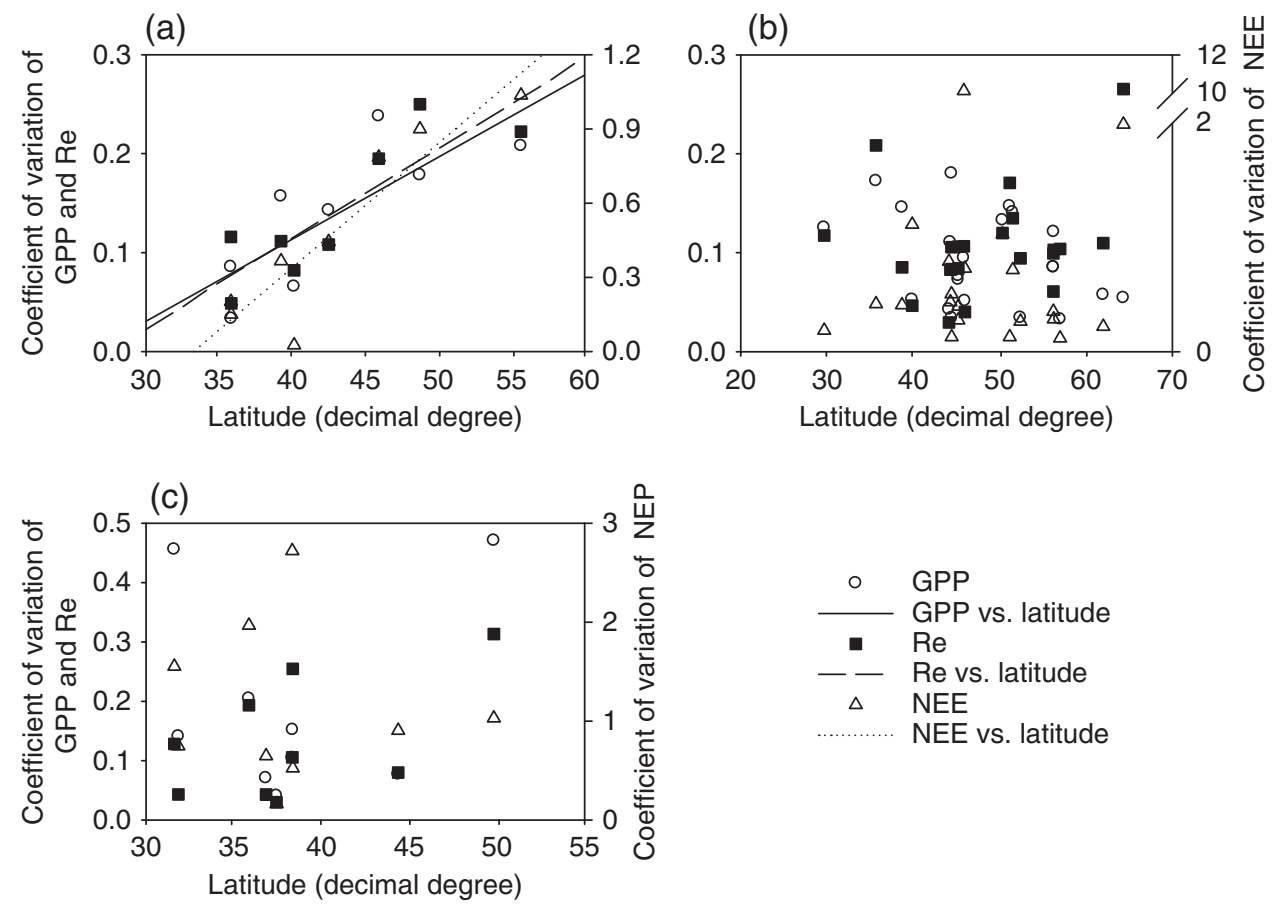

Fig. 5 Latitudinal patterns of coefficient of variation (CV) of GPP, Re and NEE in different ecosystems: (a) deciduous broadleaf forests; (b) evergreen needleleaf forests; (c) grasslands. The regression lines are presented if the correlations are significant, in (a) GPP $=0.01 \mathrm{Lat}-$ $0.22, R^{2}=0.60, P<0.05 ; \mathrm{Re}=0.01$ Lat $-0.25, R^{2}=0.73, P<0.01 ; \mathrm{NEE}=0.05$ Lat $-1.71, R^{2}=0.84, P<0.01$. Lat, latitude; NEE, net ecosystem exchange; GPP, gross primary production; Re, ecosystem respiration.

occurring mostly during the leafless nongrowing season (Palmroth et al. 2005). Thus, Re was more important in regulating NEE in deciduous broadleaf forests than in evergreen needleleaf forests.

Because GPP and Re are correlated very well (Janssens et al., 2001), the correlation of NEE with either GPP or Re will involve the interaction of GPP and Re. The correlation of NEE with either GPP or Re will decrease compared with that when GPP and Re were uncorrelated (Richardson et al., 2007a). So, in order to quantify how much the covariance between GPP and Re influences the spatial patterns in NEE, the total variance of NEE was partitioned into three components:

$$
\begin{aligned}
\operatorname{Var}(N E E)= & \operatorname{Var}(G P P)+\operatorname{Var}(R e)-2 \\
& \times \operatorname{Covar}(G P P, R e),
\end{aligned}
$$

where Var indicates the variance of specific variable, and Covar indicates covariance. The results showed variance of $\operatorname{Re}\left(1.05 \times 10^{5} \mathrm{~g}^{2} \mathrm{C} \mathrm{m}^{-4} \mathrm{yr}^{-2}\right)$ was much larger than variance of GPP $\left(3.03 \times 10^{4} \mathrm{~g}^{2} \mathrm{C} \mathrm{m}^{-4} \mathrm{yr}^{-2}\right)$ and covariance of GPP and Re $\left(3.83 \times 10^{4} \mathrm{~g}^{2} \mathrm{Cm}^{-4} \mathrm{yr}^{-2}\right)$ in deciduous broadleaf forests, and variance of GPP $\left(2.19 \times 10^{5}\right.$ $\left.\mathrm{g}^{2} \mathrm{C} \mathrm{m}^{-4} \mathrm{yr}^{-2}\right)$ was the largest component in evergreen needleleaf forest $\left[\operatorname{Var}(\operatorname{Re})=1.12 \times 10^{5} \mathrm{~g}^{2} \mathrm{C} \mathrm{m}^{-4} \mathrm{yr}^{-2}\right.$ and Covar(GPP, Re) $\left.=1.32 \times 10^{5} \mathrm{~g}^{2} \mathrm{Cm}^{-4} \mathrm{yr}^{-2}\right]$, which supported the conclusion that GPP and Re were the primary determinant of the spatial pattern of NEE in evergreen needleleaf forests and deciduous broadleaf forests, respectively.

Our finding, that Re in deciduous broadleaf forests showed an increasing trend with latitude, is consistent with results of Valentini et al. (2000). However, other studies have suggested a positive (van Dijk \& Dolman, 2004) or neutral (Enquist et al., 2003) relationship between annual temperature and respiration across regional scales. On a global scale, at individual sites plant and soil respiration rates generally increase with temperature (Raich \& Schlesinger, 1992; Chapin et al., 2002). However, variation in Re across regions is not only affected by temperature but also regulated by other abiotic and biotic factors, such as precipitation, soil microbial activity, vegetation productivity, and soil carbon content. For example, a significant correlation was observed between annual Re and GPP across undisturbed forests, and no relationship between Re and mean annual temperature across sites (Janssens et al., 2001). In addition, a global scale analysis showed that the turnover of soil organic carbon in forest is remarkably constant across the gradient in mean annual temperature, and that increased temperature alone will not stimulate the decomposition of forest-derived carbon in mineral soil (Giardina \& Ryan, 2000). Thus, when soil 
Table 2 Environmental correlations of mean annual values (MAV), absolute interannual variability (AIAV) and relative interannual variability (RIAV) of GPP, Re and NEE at different ecosystems

\begin{tabular}{|c|c|c|c|c|c|c|c|}
\hline Ecosystem & & MAV & & AIAV & & RIAV & \\
\hline \multirow[t]{3}{*}{$\mathrm{DBF}$} & GPP & - & - & - & - & $T_{\mathrm{a}}$ & $\begin{array}{c}y=1.26 x-0.001 \dagger \\
R^{2}=0.95^{* *}\end{array}$ \\
\hline & $\operatorname{Re}$ & - & - & - & - & $T_{\mathrm{a}}$ & $\begin{array}{c}y=0.74 x+0.04 \dagger \\
R^{2}=0.77^{* *}\end{array}$ \\
\hline & NEE & $T_{\mathrm{a}} \ddagger$ & $\begin{array}{c}y=52 x-321 \\
R^{2}=0.68^{* *}\end{array}$ & - & - & $T_{\mathrm{a}}$ & $\begin{array}{c}y=4.13 x-0.07 \dagger \\
R^{2}=0.78^{* *}\end{array}$ \\
\hline \multirow[t]{5}{*}{ ENF } & GPP & $T_{\mathrm{a}}$ & $\begin{array}{r}y=75 x+591 \\
R^{2}=0.69^{* *}\end{array}$ & - & - & - & - \\
\hline & & Prec & $\begin{array}{c}y=0.68 x+648 \\
R^{2}=0.36^{*}\end{array}$ & - & - & - & - \\
\hline & $\operatorname{Re}$ & $T_{\mathrm{a}}$ & $\begin{array}{c}y=52 x+563 \\
R^{2}=0.64^{* *}\end{array}$ & - & - & - & - \\
\hline & & Prec & $\begin{array}{c}y=0.54 x+527 \\
R^{2}=0.46^{* *}\end{array}$ & - & - & - & - \\
\hline & NEE & $T_{\mathrm{a}}$ & $\begin{array}{c}y=22 x+10 \\
R^{2}=0.3^{*}\end{array}$ & - & - & - & - \\
\hline \multirow[t]{3}{*}{ GRS } & GPP & Prec & $\begin{array}{c}y=0.97 x+108 \\
R^{2}=0.87^{* *}\end{array}$ & Prec\$ & $\begin{array}{c}y=0.96 x+14 \\
R^{2}=0.4^{*}\end{array}$ & Prec & $\begin{array}{c}y=0.65 x+0.06 \\
R^{2}=0.41^{*}\end{array}$ \\
\hline & $\operatorname{Re}$ & Prec & $\begin{array}{r}y=0.96 x+77 \\
R^{2}=0.91^{* *}\end{array}$ & Prec & $\begin{array}{c}y=1.18 x-22 \\
R^{2}=0.63^{* *}\end{array}$ & Prec & $\begin{array}{c}y=0.56 x+0.02 \\
R^{2}=0.56^{* *}\end{array}$ \\
\hline & NEE & - & - & - & - & - & - \\
\hline
\end{tabular}

$\dagger$ Two European sites are excluded from the regression analyses.

$\ddagger T_{\mathrm{a}}$ is the mean annual temperature $\left({ }^{\circ} \mathrm{C}\right)$.

$\S$ Prec is the annual precipitation $(\mathrm{mm}) . x$ in regression equation represent mean annual value, AIAV or RIAV of environmental variables, and $y$ represent mean annual value, AIAV or RIAV of GPP, Re and NEE.

* Significant level at $P<0.05$.

**Significant level at $P<0.01$.

DBF, deciduous broadleaf forests; ENF, evergreen needleleaf forests; GRS, grasslands; NEE, net ecosystem exchange; GPP, gross primary production; $\mathrm{Re}$, ecosystem respiration.

organic matter and resultant basal respiration rates increase with latitude, $\mathrm{Re}$ is likely to be positively correlated with latitude (Valentini et al., 2000; Enquist et al., 2003).

\section{Regulation of IAV of GPP, Re, and NEE in forests}

Our results showed temperature accounted for 95\%, $77 \%$, and $78 \%$ of RIAV in GPP, Re, and NEE in deciduous broadleaf forests, respectively (Fig. 6). The thermal regulations resulted in increasing latitudinal patterns of RIAV in GPP, Re, and NEE followed with that of temperature (Fig. 8a). In contrast with the deciduous broadleaf forest, RIAV in NEE did not show significant latitudinal trend in evergreen needleleaf forests although the RIAV of temperature increased significantly with the latitude (Fig. 8b), even if data were analyzed in North American and Europe separately (data not shown).

Temperature influences almost all ecosystem carbon cycle processes in various ecosystem types (Johnson et al., 1974). In particular, interannual variation in length of the growing season, resulting from temperature variation, accounts for much of IAV in NEE (Urbanski et al., 2007). Although correlations between annual NEE and the length of growing season exists at various ecosystems, canopy development results in greater inhibition to NEE in deciduous broadleaf forests compared with quick recovery in evergreen needleleaf forests (Black et al., 2000; Barr et al., 2002). Changes in canopy duration (mainly through adjustment of spring leaf-out) have been shown to be the most important determinant of the IAV of net carbon uptake in deciduous broadleaf forests (Barr et al., 2006). However, evergreen needleleaf forests do not appear to respond to temperature to the extent that deciduous forests (Arain et al., 2002; Kljun et al., 2006). The reduced sensitivity at the evergreen needleleaf forests may be partially caused by soils that are somewhat more buffered from air temperature increases as compared with those at the deciduous broadleaf forests (Welp et al., 2007). On the other hand, IAV in NEE in evergreen 

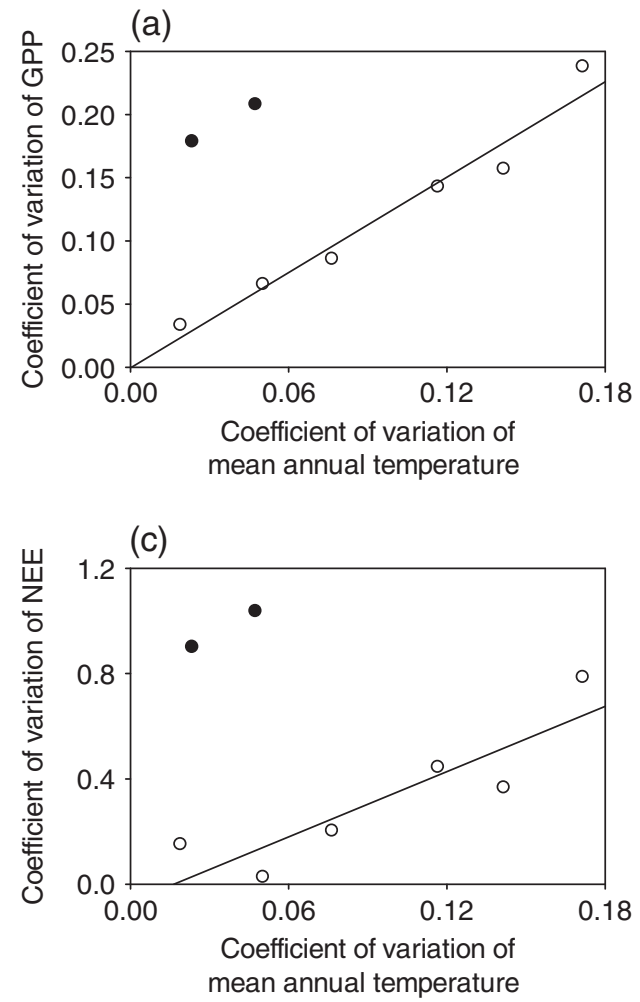

(b)

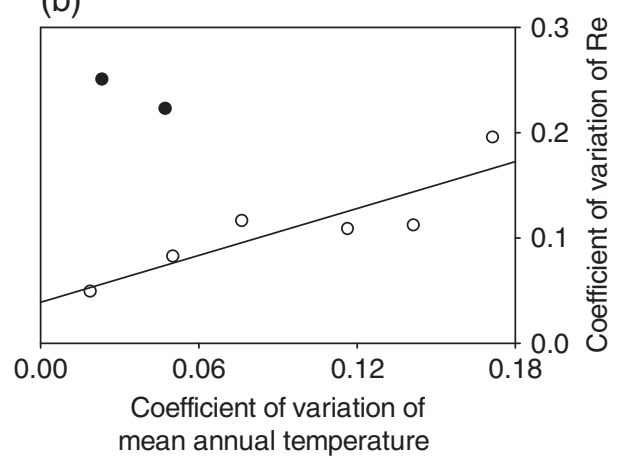

North American sites
- Regression line in North
American sites
- Two European sites

Fig. 6 Relationships between coefficient of variation (CV) of mean annual temperature and CV of GPP (a) Re (b) and NEE (c) in deciduous broadleaf forests. Open circles indicate the data in North American sites, and filled dots indicate the data of two European sites which were excluded from the regression analyses. Solid line represent regression line of GPP, Re, and NEE (GPP: $y=1.26 x-0.001$, $R^{2}=0.95, P<0.01$; Re: $y=0.74 x+0.04, R^{2}=0.77, P<0.01$; NEE: $\left.y=4.13 x-0.07, R^{2}=0.78, P<0.01\right)$. NEE, net ecosystem exchange; GPP, gross primary production; Re, ecosystem respiration.

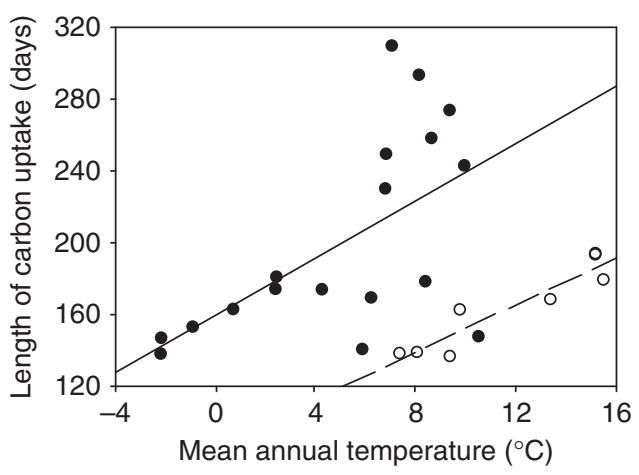

Fig. 7 Comparison of the length of carbon uptake (LCU) between deciduous broadleaf forests and evergreen needleleaf forests. Filled circles represent the data in evergreen needleleaf forests, and solid line represents regression line between LCU and mean annual temperature (MAT) (LCU $=7.97 \mathrm{MAT}+159$, $\left.R^{2}=0.34, P<0.05\right)$. Open circles indicate the data in deciduous broadleaf forests, and dashed line represents the regression line $\left(\mathrm{LCU}=6.60 \mathrm{MAT}+85, R^{2}=0.87, P<0.01\right)$.

needleleaf forests could also result from counteracting environmental regulations across the regional scales. For example, a black spruce forest changed from a modest source into a weak sink of atmospheric $\mathrm{CO}_{2}$ because net uptake was enhanced and respiration was inhibited by multiple years of rainfall in excess of evaporative demand (Dunn et al., 2007): a $2 \mathrm{~cm}$ drop in water table depth over the 100 days increased Re by $18 \mathrm{~g} \mathrm{C} \mathrm{m}^{-2}$ annually, which was enough to change the overall carbon balance from a sink to a source. Furthermore, lag effects of environmental variables to ecosystems are important for regulating IAV in NEE in evergreen needleleaf forests. Compared with climate moisture index (CMI, difference between annual precipitation and potential ET) of current year, CMI of previous 3 years accounted for more variability of NEE (Dunn et al., 2007), which suggested that the effects of precipitation anomalies on carbon exchange may only be evident after several years of drought or wetness. As a consequence, there are no significant environmental variables that can account for IAV in NEE and resulted in significant latitudinal patterns in evergreen needleleaf forests.

There were no significant latitudinal trends of AIAV of NEE in either deciduous broadleaf or evergreen needleleaf forests. Although AIAV and RIAV in GPP 

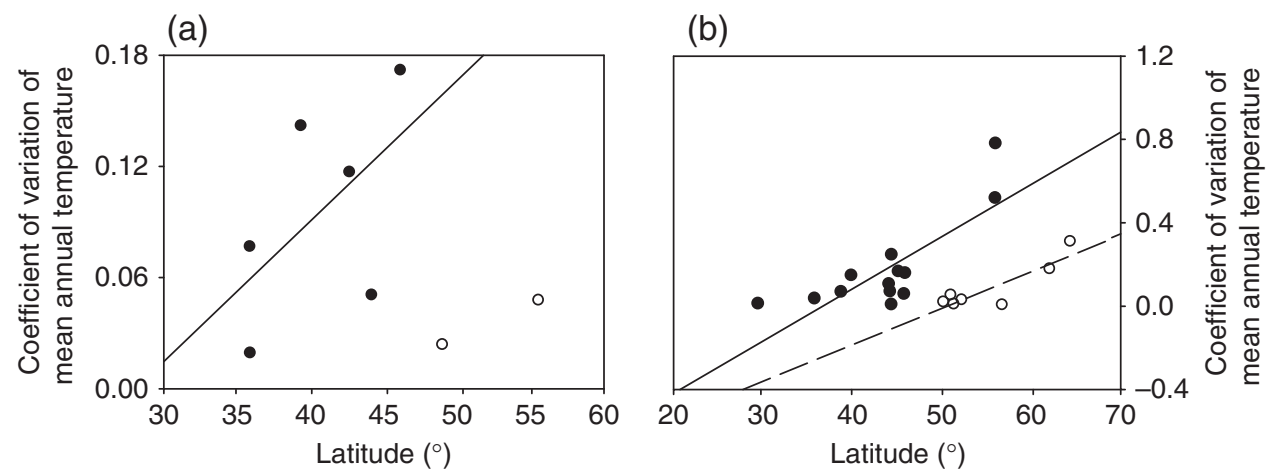

Fig. 8 Latitudinal patterns of coefficient of variation (CV) of mean annual temperature in (a) deciduous broadleaf forests and (b) evergreen needleleaf forests. Filled circles represent the data in North American, and solid line represents regression line between CV of mean annual temperature (CVMAT) and the latitude (Lat) [in (a) CVMAT $=0.01$ Lat $-0.21, R^{2}=0.31, P=0.2$; in (b) CVMAT $=0.02 \mathrm{Lat}-$ $\left.0.89, R^{2}=0.76, P<0.01\right]$. Open circles indicate the data in European, and dashed line represents the regression line [in (b) CVMAT $=0.02$ Lat $\left.-0.92, R^{2}=0.62, P<0.01\right]$

and Re varied significantly with latitude in deciduous broadleaf forests, but no environmental factors were found to be responsible for them (data not shown). A probable cause is that observed IAV is due not only to variation in environmental drivers, but also to metabolic changes (Hui et al., 2003). For example, one modeling analysis (Richardson et al., 2007a) suggested that, at the annual time step, about $40 \%$ of the variance in modeled NEE could be attributed to variation in environmental drivers, and 55\% to variation in the biotic response to this forcing (i.e., basal rates and environmental sensitivities of photosynthesis and respiration). Underlying causes for metabolic changes have not yet been elucidated, but may include indirect effects of climate on ecosystem processes and biogeochemical cycling.

\section{Environmental regulation of IAV in NEE in grasslands}

Precipitation is the dominant environmental variable for the across-site variation and within-site interannual variation in ecosystem carbon balance, especially arid and semiarid ecosystems (Knapp \& Smith, 2001; Flanagan et al., 2002, Flanagan \& Johnson, 2005; Suyker et al., 2003; Li et al., 2005). It is widely accepted that increasing precipitation promotes the grasslands vegetation production across the spatial scales (Sala et al., 1988; Lauenroth \& Sala, 1992; Jobbágy \& Sala, 2000; Jobbágy et al., 2002; Bai et al., 2004). Our result showed that annual mean precipitation was a strong predictor of spatial patterns of average GPP in grasslands, which accounted for $87 \%$ spatial variation of GPP. Compared with the well-developed knowledge of precipitation regulation to GPP, relatively few studies at the regional scales have presented spatial variation of Re in grasslands. In this study, mean annual precipitation ex- plained 91\% spatial variation of Re. Recent studies have demonstrated the strong coupling between GPP and $\mathrm{Re}$, with respect to physiological couplings and environmental drivers, and this coupling exists from diurnal, seasonal to annual time scale (Janssens et al., 2001; Tang et al., 2005; Stoy et al., 2008), which showed the promising causes for precipitation regulating spatial patterns of Re across broad scales.

In addition, our correlation analyses showed significant correlation of precipitation with GPP and Re in both AIAV and RIAV. A number of studies within individual sites have showed precipitation is the major cause for IAV in GPP and Re (Craine et al., 1999; Flanagan et al., 2002; Li et al., 2005; Jacobs et al., 2007). For example, Luo et al. (1996) have shown that grassland soil respiration was more strongly linked to changes in carbon availability and soil moisture than to shifts in temperature. However, relatively few studies have reported symmetry of ecosystem response to variation in precipitation at the region scale. Across the timescales, grasslands have very large asymmetric responses to variation in precipitation. For example, productivity increases in wet years are much more pronounced than reductions in productivity during drought years (Knapp \& Smith, 2001). Significant correlation of SD between precipitation and GPP showed the same sensitivity in grasslands to AIAV in precipitation under the various water conditions. In generally, precipitation showed the larger AIAV at the wet regions (data not shown), and which resulted in larger AIAV in GPP.

Generally, our results showed that precipitation was dominant of spatial patterns of magnitude and IAV in GPP and Re in grasslands. Strong sensitivity of GPP and $\operatorname{Re}$ to precipitation resulted in the weak latitudinal patterns because IAV in precipitation did not have significant correlations with latitude. However, spatial 
changes in precipitation did not explained variation in NEE, and the parallel and offsetting responses of GPP and Re to precipitation across the sites probably were the major cause for this nonsignificant relationship. Furthermore, our results showed higher NEE of grasslands in the high latitude than low latitude regions, which was opposite to that in forests (Fig. 2). Causes of increasing NEE with latitude were not clear.

\section{Ages effects on forest carbon fluxes}

A number of chronosequence studies have investigated the effect of stand age on NEE in forest ecosystems (Clark et al., 2004; Desai et al., 2005), which would overshadow the effects of other driving forces and regulate the spatial patterns of carbon balance (Baldocchi, 2008). Odum's theory of forest succession (Odum, 1969) hypothesizes that GPP rapidly increases and then decreases as forests age, while Re increases monotonically due to the increase in respiratory substrate (biomass, litter falls soil organic content etc.). As a result, net carbon uptake increases with stand age, reaching the maximum net carbon uptake between 50 and 200 years, and then approaches to the carbon neutral (Law et al., 2004; Arain \& Restrepo-Coupe, 2005; Baldocchi, 2008). However, it is important to note that Odum's hypothesis was based on a single time series of temperate forest succession (Kira \& Shidei, 1967; Stoy et al., 2008). Across the spatial scales, forests reached the maximum net carbon uptake at the different stand age, and the succession showed the independent effects with other driving forces (e.g. climate, soil, respiratory substrate) (Magnani et al., 2007). Furthermore, recent study also showed old-growth forest stands can accumulate carbon, contrary to the long-standing view that they are carbon neutral (Luyssaert et al., 2008). In this study, large net carbon uptake occurred in various stand age stages from 10-year (Blodgett) to more than 100 years (Tharandt) (Fig. 9), which suggested stand age did not show the significant regulations of spatial patterns of carbon balance.

\section{Summary}

This study has assessed spatial distribution of NEE and its IAV across three major types of terrestrial ecosystems. Our results showed that mean annual NEE significantly decreased with latitude in both deciduous broadleaf forests and evergreen needleleaf forests, but increased in grasslands. Correlation analyses indicated that GPP and Re played a dominant role in regulating spatial variations of NEE in evergreen needleleaf forests and deciduous broadleaf forests, respectively. Furthermore, RIAV in NEE significantly increased with latitude

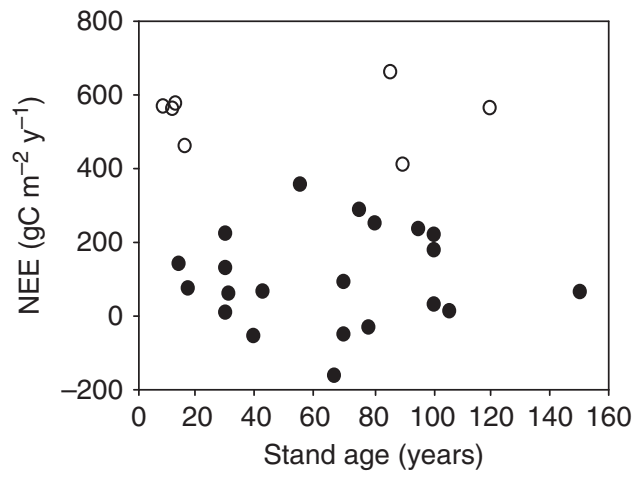

Fig. 9 The correlation between stand age and NEE in the forest ecosystems. Open dots represent the sites with large net carbon uptake $\left(>400 \mathrm{~g} \mathrm{C} \mathrm{m}^{-2} \mathrm{yr}^{-1}\right.$ ), and these sites are Blodgett, Donaldson, Aberfeldy, Duke Pine, Walker Brach, Duke Hardwood, and Tharandt in chronological order. Positive values at $y$-axes indicate that carbon is absorbed by the ecosystems, while negative values indicate that carbon is released by the ecosystems to the atmosphere. NEE, net ecosystem exchange.

in deciduous broadleaf forests and tended to be constant with latitude in evergreen needleleaf forests and grasslands. RIAV of temperature accounted for the spatial patterns of RIAV in GPP, Re, and NEE in deciduous broadleaf forests. In grasslands, RIAV in GPP and Re was responsive to RIAV of precipitation. However, none of the chosen climatic factors could explain RIAV in GPP, Re and NEE in evergreen needleleaf forests.

\section{Acknowledgements}

This research was financially supported by US National Science Foundation (NSF) under DEB 0444518, and by the Terrestrial Carbon Program at the Office of Science, US Department of Energy, Grants No.: DE-FG03-99ER62800 and DE-FG02006ER64317 to YL. Andrew D. Richardson was partially supported by the Office of Science (BER), US Department of Energy, under interagency agreement DE-AI02-07ER64355 and DOE-NICCR agreement DE-FG02- 06ER64157 and through the Northeastern Regional Center of the National Institute for Climatic Change Research. We acknowledge the work of principal investigators and collaborators in EC sites, who provided the eddy covariance flux measurements.

\section{References}

Arain MA, Black TA, Barr AG, Jarris PG, Massheder JM, Verseghy DL, Nesic Z (2002) Effects of seasonal and interannual climate variability on net ecosystem productivity of boreal deciduous and conifer forests. Canadian Journal of Forest Research, 32, 878-891.

Arain MA, Restrepo-Coupe N (2005) Net ecosystem production in a temperate pine plantation in southeastern Canada. Agricultural and Forest Meteorology, 128, 223-241. 
Bai YF, Han XG, Wu JG, Chen ZZ, Li LH (2004) Ecosystem stability and compensatory effects in the Inner Mongolia grassland. Nature, 431, 181-184.

Baldocchi DD (2008) 'Breathing' of the terrestrial biosphere: lessons learned from a global network of carbon dioxide flux measurement systems. Australian Journal of Botany, 56, $1-26$.

Baldocchi DD, Falge E, Gu LH et al. (2001) FLUXNET: a new tool to study the temporal and spatial variability of ecosystemscale carbon dioxide, water vapor, and energy flux densities. Bulletin of the American Meteorological Society, 82, 2415-2434.

Baldocchi DD, Xu LK, Kiang N (2004) How plant functional type, weather, seasonal drought, and soil physical properties alter water and energy fluxes of an oak-grass savanna and an annual grassland. Agricultural and Forest Meteorology, 123, 1339.

Barr AG, Black TA, Hogg EH et al. (2006) Climatic controls on the carbon and water balances of a boreal aspen forest, 1994-2003. Global Change Biology, 13, 561-576.

Barr AG, Griffis TJ, Black TA et al. (2002) Comparing the carbon budgets of boreal and temperate deciduous forest stands. Canadian Journal of Forest Research, 32, 813-822.

Black TA, Chen WJ, Barr AG, Cook BD, Wang W (2000) Increased carbon sequestration by a boreal deciduous forest in years with warm spring. Geophysical Research Letters, 27, 1271-1274.

Bolstad PV, Davis KJ, Martin JM et al. (2004) Component and whole-system respiration fluxes in northern deciduous forests. Tree Physiology, 24, 493-504.

Bousquet P, Peylin P, Ciais P et al. (2000) Regional changes in carbon dioxide fluxes of land and oceans since 1980. Science, 290, 1342-1346.

Canadell JG, Pataki D, Gifford R et al. (2007) Saturation of the terrestrial carbon sink. In: Terrestrial Ecosystems in a Changing World. IGBP Series (eds Canadell JG, Pataki D, Pitelka L), pp. 81-100. Springer, Berlin.

Carrara A, Kowalski AS, Neirynck J et al. (2003) Net ecosystem $\mathrm{CO}_{2}$ exchange of mixed forest in Belgium over 5 years. Agricultural and Forest Meteorology, 119, 209-227.

Chapin FS, Matson PA, Mooney HA (2002) Principles of Terrestrial Ecosystem Ecology. Springer-Verlag, New York.

Clark KJ, Gholz HL, Castro MS (2004) Carbon dynamics along a chronosequence of slash pine plantations in north Florida. Ecological Applications, 14, 1154-1171.

Craine FM, Wedin DA, Chapin FS III (1999) Predominance of ecophysiological controls on soil $\mathrm{CO}_{2}$ flux in a Minnesota grassland. Plant and Soil, 207, 77-86.

Desai AR, Bolstad PV, Cook BD, Daris KJ, Carey EV (2005) Comparing net ecosystem exchange of carbon dioxide between an old-growth and mature forest in the upper Midwest, USA. Ecological Applications, 14, S22-S32.

Desai AR, Richardson AD, Moffat AM et al. (2008) Cross site evaluation of eddy covariance GPP and RE decomposition techniques. Agricultural and Forest Meteorology, 148, 821-838.

Dolman AJ, Moors EJ, Elbers JA (2002) The carbon uptake of a mid latitude pine forest growing on sandy soil. Agricultural and Forest Meteorology, 111, 157-170.

Dunn AL, Barford CC, Wofsy SC, Goulden ML, Daube BC (2007) A long-term record of carbon exchange in a boreal black spruce forest: means, responses to interannual variability, and decadal trends. Global Change Biology, 13, 577-590.

Enquist BJ, Economo EP, Huxman TE, Allen AP, Ignace DD, Gillooly JF (2003) Scaling metabolism from organisms to ecosystems. Nature, 423, 639-642.

Falge E, Baldocchi D, Olson R et al. (2001) Gap filling strategies for defensible annual sums of net ecosystem exchange. Agricultural and Forest Meteorology, 107, 43-69.

Fan S, Gloor M, Mahlman J, Pacalas S, Sarmiento J, Takahashi T, Tans P (1998) A large terrestrial carbon sink in North America implied by atmospheric and oceanic carbon dioxide data and models. Science, 282, 442-446.

Flanagan LB, Johnson BG (2005) Interacting effects of temperature, soil moisture and plant biomass production on ecosystem respiration in a northern temperate grassland. Agricultural and Forest Meteorology, 130, 237-253.

Flanagan LB, Wever LA, Carlson PJ (2002) Seasonal and interannual variation in carbon dioxide exchange and carbon balance in a northern temperate grassland. Global Change Biology, 8, 599-615.

Friend AD, Arneth A, Kiang NY et al. (2007) FLUXNET and modelling the global carbon cycle. Global Change Biology, 13, 610-633.

Gholz HL, Clark KL (2002) Energy exchange across a chronosequence of slash pine forests in Florida. Agricultural and Forest Meteorology, 112, 87-102.

Giardina CP, Ryan MG (2000) Evidence that decomposition rates of organic carbon in mineral soil do not vary with temperature. Nature, 404, 858-861.

Goldstein AH, Hultman NE, Fracheboud JM et al. (2000) Effects of climate variability on the carbon dioxide, water, and sensible heat fluxes above a ponderosa pine plantation in the Sierra Nevada (CA). Agricultural and Forest Meteorology, 101, 113-129.

Goulden ML, Munger JW, Fan SM, Daube BC, Wofsy SC (1996) Exchange of carbon dioxide by a deciduous forest: response to interannual climate variability. Science, 271, 1576-1578.

Goulden ML, Winston GC, McMillan AMS et al. (2006) An eddy covariance mesonet to measure the effect of forest age on landatmosphere exchange. Global Change Biology, 12, 2146-2162.

Granier A, Ceschia C, Damesin C et al. (2000) The carbon balance of a young Beech forest. Functional Ecology, 14, 312-325.

Grünwald T, Berhofer C (2007) A decade of carbon, water and energy flux measurements of an old spruce forest at the Anchor Station Tharandt. Tellus, 59B, 387-396.

Gurney KR, Law RM, Denning AS et al. (2002) Towards robust regional estimates of $\mathrm{CO}_{2}$ sources and sinks using atmospheric transport models. Nature, 415, 626-630.

Hollinger DY, Aber J, Dail B et al. (2004) Spatial and temporal variability in forest-atmosphere $\mathrm{CO}_{2}$ exchange. Global Change Biology, 10, 1689-1706.

Houghton RA (2000) Interannual variability in the global carbon cycle. Journal of Geophysical Research, 105, 20,121-20,130.

Hui DF, Luo YQ, Katul G (2003) Partitioning interannual variability in net ecosystem exchange between climatic variability and functional change. Tree Physiology, 23, 433-442.

IPCC (2001) Climate change 2001: the scientific basis. Contribution of Working Group I to the Third Assessment Report of the 
Intergovernmental Panel on Climate Change (eds Houghton JT, Ding Y, Griggs DJ, Noguer M, Linden PJ, Dai X, Maskell K, Johnson CA), pp. 105-118. Cambridge University Press, Cambridge, UK and New York, NY, USA.

IPCC (2007) Climate change 2007: the physical science basis. Contribution of Working Group I to the Fourth Assessment Report of the Intergovernmental Panel on Climate Change (eds Solomon S, Qin D, Manning M, Chen Z, Marquis M, Averyt KB, Tignor M, Miller HL), pp. 241-254. Cambridge University Press, Cambridge, UK and New York, NY, USA.

Jacobs AFG, Heusinkveld BG, Holtslag AAM (2007) Seasonal and interannual variability of carbon dioxide and water balances of a grassland. Climatic Change, 82, 163-177.

Janssens IA, Lankreijer H, Matteucci G et al. (2001) Productivity overshadows temperature in determining soil and ecosystem respiration across European forests. Global Change Biology, 7, 269-278.

Jarvis PG, Dolman AJ, Schulze ED et al. (2001) Carbon balance gradient in European forests: should we doubt 'surprising' results? A reply to Piovesan \& Adams. Journal of Vegetation Science, 12, 145-150.

Jobbágy EG, Sala OE (2000) Controls of grass and shrub aboveground production in the Patagonian steppe. Ecological Applications, 10, 541-549.

Jobbágy EG, Sala OE, Paruelo JM (2002) Patterns and controls of primary production in the Patagonian steppe: a remote sensing approach. Ecology, 83, 307-319.

Johnson FH, Eyring H, Stover BJ (1974) The Theory of Rate Processes in Biology and Medicine. John Wiley \& Sons, New York, NY.

Kato T, Tang YH (2008) Spatial variability and major controlling factors of $\mathrm{CO}_{2}$ sink strength in Asian terrestrial ecosystems: evidence from eddy covariance data. Global Change Biology, 14, 2333-2348.

Kira T, Shidei T (1967) Primary production and turnover of organic matter in different forest ecosystems of the western Pacific. Japanese Journal of Ecology, 17, 70-87.

Kljun N, Black TA, Griffis T et al. (2006) Response of net ecosystem productivity of three boreal forest stands to drought. Ecosystems, 9, 1128-1144.

Knapp AK, Smith MD (2001) Variation among biomes in temporal dynamics of aboveground primary production. Science, 291, 481-484.

Lauenroth WK, Sala OE (1992) Long-term forage production of north American shortgrass steppe. Ecological Applications, 2, 397-403.

Law BE, Falge E, Gu L et al. (2002) Environmental controls over carbon dioxide and water vapor exchange of terrestrial vegetation. Agricultural and Forest Meteorology, 113, 97-120.

Law BE, Turner D, Campbell J, Sun OJ, Tuyl SV, Ritts WD, Cohen WB (2004) Disturbance and climate effects on carbon stocks and fluxes across Western Oregon USA. Global Change Biology, 10, 1429-1444.

Law BE, Williams M, Anthoni PM, Baldocchi D, Unsworth MH (2000) Measuring and modelling seasonal variation of carbon dioxide and water vapour exchange of a Pinus ponderosa forest subject to soil water deficit. Global Change Biology, 6, 613630 .
Li SG, Asanuma J, Eugster W et al. (2005) Net ecosystem carbon dioxide exchange over grazed steppe in central Mongolia. Global Change Biology, 11, 1941-1955.

Lindroth A, Grelle A, Moren AS (1998) Long-term measurements of boreal forest carbon balance reveal large temperature sensitivity. Global Change Biology, 4, 443-450.

Lloyd J, Taylor JA (1994) On the temperature dependence of soil respiration. Functional Ecology, 8, 315-323.

Luo YQ, Jackson RB, Field CB, Mooney HA (1996) Elevated $\mathrm{CO}_{2}$ increases belowground respiration in California grasslands. Oecologia, 108, 130-137.

Luyssaert S, Schulze ED, Börner A et al. (2008) Old-growth forests as global carbon sinks. Nature, 455, 213-215.

Magnani F, Mencuccini M, Borghetti M et al. (2007) The human footprint in the carbon cycle of temperature and boreal forests. Nature, 447, 848-850.

Monson RK, Sparks JP, Rosenstiel TN et al. (2005) Climatic influences on net ecosystem $\mathrm{CO}_{2}$ exchange during the transition from wintertime carbon source to springtime carbon sink in a high-elevation, subalpine forest. Oecologia, 146, 130-147.

Novick KA, Stoy PC, Katul GG, Ellsworth DS, Siqueira M, Juang J, Oven R (2004) Carbon dioxide and water vapor exchange in a warm temperate grassland. Oecologia, 138, 259-274.

Oberbauer SF, Tweedie CE, Welker JM et al. (2007) Tundra $\mathrm{CO}_{2}$ fluxes in response to experimental warming across latitudinal and moisture gradients. Ecological Monographs, 77, 221-238.

Odum EP (1969) The strategy of ecosystem development. Science, 164, 262-270.

Palmroth S, Maier CA, McCarthy HR et al. (2005) Contrasting responses to drought of forest floor $\mathrm{CO}_{2}$ efflux in a Loblolly pine plantation and a nearby Oak-Hickory forest. Global Change Biology, 11, 421-434.

Papale D, Reichstein M, Aubinet M et al. (2006) Towards a standardized processing of net ecosystem exchange measured with eddy covariance technique: algorithms and uncertainty estimation. Biogeosciences, 3, 571-583.

Pataki DE, Oren R (2003) Species differences in stomatal control of water loss at the canopy scale in a mature bottomland deciduous forest. Advances in Water Resources, 26, 1267-1278.

Paw UKT, Falk M, Suchanek TH et al. (2004) Carbon dioxide exchange between an old-growth forest and the atmosphere. Ecosystems, 7, 513-524.

Pilegaard K, Hummelshoj P, Jensen NO, Chen Z (2001) Two years of continuous $\mathrm{CO}_{2}$ eddy-flux measurements over a Danish beech forest. Agricultural and Forest Meteorology, 107, 29-41.

Raich JW, Schlesinger WH (1992) The global carbon dioxide flux in soil respiration and its relationship to vegetation and climate. Tellus, 44B, 81-99.

Räisänen J (2002) $\mathrm{CO}_{2}$-induced changes in interannual temperature and precipitation variability in 19 CMIP2 experiments. Journal of Climate, 15, 2395-2411.

Reichstein M, Falge E, Baldocchi D et al. (2005) On the separation of net ecosystem exchange into assimilation and ecosystem respiration: review and improved algorithm. Global Change Biology, 11, 1424-1439.

Richardson AD, Hollinger DY, Aber JD, Ollinger SV, Braswell BH (2007a) Environmental variation is directly responsible for 
short- but not long-term variation in forest-atmosphere carbon exchange. Global Change Biology, 13, 788-803.

Richardson AD, Jenkins JP, Braswell BH, Hollinger DY, Ollinger SV, Smith ML (2007b) Use of digital webcam images to track spring green-up in a deciduous broadleaf forest. Oecologia, 152, 323-334.

Sala OE, Parton WJ, Joyce LA, Lauenroth WK (1988) Primary production of the central grassland region of the United States. Ecology, 69, 40-45.

Schmid HP, Grimmond CSB, Cropley F, Offerle B, Su HB (2000) Measurements of $\mathrm{CO}_{2}$ and energy fluxes over a mixed hardwood forest in the mid-western United States. Agricultural and Forest Meteorology, 103, 357-374.

Scott RL, Cable WL, Hultine KR (2008) The ecohydrologic significance of hydraulic redistribution in a semiarid savanna. Water Resources Research, 44, W02440, doi: 10.1029/2007WR 006149.

Simmons JA, Fernandez IJ, Briggs RD, Delaney MT (1996) Forest floor carbon pools and fluxes along a regional climate gradient in Maine, USA. Forest Ecology and Management, 84, 81-95.

Song J, Liao K, Coulter RL, Lesht BM (2005) Climatology of the low-level jet at the southern great plains atmospheric boundary layer experiments site. Journal of Applied Meteorology, 44, 15931606.

Stoy PC, Katul GG, Siqueira MBS et al. (2006) An evaluation of methods for partitioning eddy covariance-measured net ecosystem exchange into photosynthesis and respiration. Agricultural and Forest Meteorology, 141, 2-18.

Stoy PC, Katul GG, Siqueira MBS et al. (2008) Role of vegetation in determining carbon sequestration along ecological succession in the southeastern United States. Global Change Biology, 14, 1409-1427.

Suni T, Rinne J, Reissel A et al. (2003) Long-term measurements of surface fluxes above a Scots pine forest in Hyytiälä, southern Finland, 1996-2001. Boreal Environment Research, 4, 287-301.

Suyker AE, Verma SB (2001) Year-round observations of the net ecosystem exchange of carbon dioxide in a native tall grass prairie. Global Change Biology, 7, 279-289.

Suyker AE, Verma SB, Burba GG (2003) Interannual variability in net $\mathrm{CO}_{2}$ exchange of a native tall grass prairie. Global Change Biology, 9, 255-265.

Tang JW, Baldocchi DD, Xu L (2005) Tree photosynthesis modulates soil respiration on a diurnal time scale. Global Change Biology, 11, 1298-1304.

Urbanski S, Barford C, Wofsy S et al. (2007) Factors controlling $\mathrm{CO}_{2}$ exchange on timescales from hourly to decadal at Harvard Forest. Journal of Geophysical Research-Biogeosciences, 112 (G2), G02020, doi: 10.1029/2006JG000293.

Valentini R (2003) Fluxes of Carbon, Water and Energy of European Forests. Springer-Verlag, Heidelberg.

Valentini R, Matteucci G, Dolman AJ et al. (2000) Respiration as the main determinant of carbon balance in European forests. Nature, 404, 861-865.

van Dijk AIJM, Dolman AJ (2004) Estimates of $\mathrm{CO}_{2}$ uptake and release among European forests based on eddy covariance data. Global Change Biology, 10, 1445-1459.

Welp LR, Randersonb JT, Liuc HP (2007) The sensitivity of carbon fluxes to spring warming and summer drought depends on plant functional type in boreal forest ecosystems. Agricultural and Forest Meteorology, 147, 172-185.

Wilson KB, Baldocchi DD (2000) Seasonal and interannual variability of energy fluxes over a broadleaved temperate deciduous forest in North American. Agricultural and Forest Meteorology, 100, 1-18.

Yuen CW, Higuchi Kand the Transcom-3 modellers (2005) Impact of Fraserdale $\mathrm{CO}_{2}$ observations on annual flux inversion of the North American boreal region. Tellus, 57, 203-209. 